\title{
One of the ways to the architectonic sacrum
}

The process of cognition usually ends with an attempt to name and understand the searched/encountered phenomenon. The essence of sacrum is not observable simply because as "we do not have direct access to the quantum world via our senses", but it does exist.

Remembering the words of L. Wittgenstein which state that "the borders of the language (the only language I understand) constitute the borders of my world", one ought to take one of the ways leading to our subject of cognition.

A direct arising in the sphere of sacrum can be both a mental and emotional anticipation of the essence of subject we are heading to, and whose spatial frame is determined by architectonic objects. In its sensory meaning sacrum materializes itself often in a form of sacred chapels, paintings, sculptures, fragments of buildings, landscape etc.

In the following article an attempt to select one of the ways that can lead to more complete contact and understanding of a sacred, materialized phenomenon which is referred to as sacrum. One, however, ought to bear in mind that the attempt at reaching the essence of such a place is a difficult task because just like "watching a wild brook does not concern the flow, the sound or reflexes of this particular brook but the general concept of a brook: unbridled push of unformed matter ${ }^{\prime \prime}$, the understanding and sensing of sacrum escapes a clear codification.

Key words: language, phenomenology, philosophy of dialogue, philosophy of encounter. 


\section{Sacrum}

Amongst many recognized objects and phenomena there is a group that is defined as sacred things. If one begins a mental journey in order to understand a given phenomenon one needs to refer to the term definition of the subject of the research. This definition specifies the direction of and constitutes a basis for dynamically shaped thoughts, which sometimes are even in contradiction to one another. Edmund Husserl did say that "specification of goals of a science is expressed by its definition"2.

It can be said that sacrum is a domain of sacred issues, around which beliefs, rituals and religious practices are concentrated. Sacrum constitutes a manifestation of order that is beyond our world and thus it is unable be verbally expressed. Sacrum in Latin means ,what is sacred, what is specific for a religion", opposite in meaning to profanum ${ }^{3}$.

An attempt to express but also to understand architectonic sacrum may be made thanks to applying mental bridges that aim at bringing the subject closer to a sacred phenomenon. The multilayer structure of the issue forces to employ a multilayer method of its perception. Uncovering the secret hidden in the harmonious space may take place in accordance with three coinciding planes in the $20^{\text {th }}$ philosophy which are the: phenomenology, philosophy of language, philosophy of dialogue.

One should remember that if a point is observed which surely can be defined as the essence of sacrum then ,with time [it] would become one thing, one of vanities or habits of home; now [sacrum] is unlimited, constant, able to take every form or every colour and not connected to anything" .

In order to gain insights into sacrum one firstly needs to calm down and clear the mind, reduce all thought conventions, reach the heart of the thing (noumenon). Later one ought to make an attempt to name this thing, find proper words and concepts and, eventually, open a dialogue with it.

\section{Phenomenology}

According to E. Husserl the cognition of an object is done by empathizing, which appears as soon as noticing of an object has occurred.

2 E. Husserl, Badania logiczne, Wydawnictwo naukowe PWN, translated by J. Sidorek, vol. 1, Warszawa 2006, p. 23.

3 J. Tokarski (ed.), Stownik wyrazów obcych PWN, PWN, Warszawa 1980, p. 661.

4 J. L. Borges, Nowa antologia osobista, Wydawnictwo Literackie, translated by A. Sobol-Jurczykowski, Kraków 2006, p. 76. 
Then one ought to reach the heart of the thing, stripping it off layers of meanings and emotions because ,gradually performed reducing operations seem to deepen the immanency, limiting the autonomy of the subject in the consciousness"5.

For the sake of effectiveness of such an action one ought to bear in mind that there has to be one subject. Sacrum is semantically subjectified; it refers to sublimated from the many, one and only concrete term. „This what it refers to occurs only in singular form or even not, not in a number but in uniqueness" 6 .

When a human being approaches sacred architectonic space the awareness of its uniqueness has to be born and carried within him. He should unite with the object of his adoration and at the same time notice genius loci, which gives it a frame. It is about an intuitive, direct perception of a source view which later ought to undergo an eidetic reduction. Husserl called this process a rule of all rules. According to it the arising from phenomenology notions of truth and certainty are striving to recognize the noumenon.

Although the author will not try to engross in the nuances between the terms being and existence one should remember that „We experience existence firstly (...) and a priori. Being is recognized later or it can be not recognized at all"' The existence of sacrum can be captured by means of a materialized frame, its essence and understanding of this essence is impossible without the interference of the Absolute.

It has to be underlined that the phenomenon of phenomenological empathizing enriches the process of experiencing of one's own Self. Preceded by a multilayer perception, engrossing in an architectonic object allows simultaneously to notice and comprehend not only the walls in position to a given subject but also other spaces, including the inside, which hides sanctification. The accurate and long-lasting perception of harmonious, complete truth, goodness and beauty of the space is, according to Leopold Blaustein, a schemata of determinants, which is characteristic for the phenomenology.

As it was mentioned all objects, including architectonic ones, may not exist separately from a context. In nature there exists a phenomenon of mutual contact of space and their mutual influence on one

$5 \quad$ E. Husserl, Medytacje kartezjańskie, Wydawnictwo IFiS PAN, translated by A. Wajs, Warszawa 2009, p. XVII.

M. Heidegger, Identyczność i różnica, Wydawnictwo Aletheia, translated by J. Mizera, Warszawa 2010, p. 59. 
another. Juliusz Żuławski greatly succeeded in describing this process in his work titled About the architectonic form.

If one follows this path that leads to the cognition of sacrum than a relevant object or a fragment of the space need to be separated from the background. Only then one can say if the sanctified and searched subject is made present visually or not visually. In both cases it undergoes perception that sometimes is vivid and sensory, and sometimes conceptual and imaginative, when it induces only the essential anticipation of the object. However, the way the subject ,perceives the world depends on what person he is (let's leave the question who is what kind of a person unanswered)" 8 .

\section{Philosophy of language}

Umberto Eco wrote that ,even the most elementary architectonic configuration is a text"9. Verbalization of a subject/notion enables its understanding. While searching for sacrum one is heading to a sanctified place. „The term place originally meant the edge of a spear. Everything ends and coincides in it. Place focuses all what is the most crucial and extreme. This what is focused permeates and transforms [durchwest] everything" 10 .

As it was mentioned, for understanding the essence of each phenomenon, even if it is made present not visually, words of which the colloquial language is made are needed. It's worth reminding that ,the colloquial language refers to nothing more than common or popular language, and its antonym is a non-colloquial language, e.g. a technical one"11.

Nickolas of Cusa directed his philosophical look at the phenomenon of a language. At the end of his line of thought he claimed that all cognition, both mathematical-natural and metaphysical, eventually becomes a language.

Beginning with Gottlob Frege, a main question in the philosophy of language concerns the relation between a language and the world, a clear thought with a thing.

8 R. Liberkowski, Przyczynek dofenomenologii życia, Uniwersytet im. A. Mickiewicza w Poznaniu, Wydawnictwo Naukowe Instytutu Filozofii, Poznań 2007, p. 38 .

U. Eco, Teoria semiotyki, Wydawnictwo Uniwersytetu Jagiellońskiego EIDOS, translated by M. Czerwiński, Kraków 2009, p. 275. Warszawa 2007, p. 27.

$11 \quad$ M. Maciejczak, Zwrot językowy $w$ filozofii od Fregego do Searle'a, Oficyna Wydawnicza Politechniki Warszawskiej, Warszawa 2010, p. 65. 
In the case when an object is made present not visually at the beginning of its perception pictures may appear, however, when in a subject a though is born, it starts to have a language shape. Naming an object triggers its understanding and using the most proper words connected with it. It ought to be remembered that the language aspect of an object that came to being before the subject can't be understood separately from a wide spectrum of culture and the way it shapes particular representatives of a given society. A broad view allows to see sacrum as „places that the most dignified and richest in memories, some kind of everyday celebrations for celebrating the achieved and possible to achieve dignity of a human mind, a newer and more complete development and representation of the idea of a scholar, which a cleric, an artist and a medic" 12 .

If on the way to conveying experiences on the topic of understanding the architectonic sacrum there is a need of naming a phenomenon, then there is no possibility to establish contact with another subject without the help of a language which these two people use. Functioning is society, wanting to be understood, one can have an impression the he is a slave of the language, which draws the border of the world, different for each individual.

One could look for isomorphism between the world of matter and a language. The architecture in its tectonics, in the spatial rules of grammar seems to have a reflection in the syntax and pragmatics of a language. Speaking a language, just like the art of shaping the space, are regulated by complex laws of social behaviours. If the similarities can be spotted and sometimes notice the same structure and properties between the architecture and natural language, it can be said the understanding sacrum without the knowledge of the language is impossible; because ,it is the language that expresses a religious experience, which is bears a cognitive, practical and emotional meaning" ${ }^{13}$.

The cognition of the world, according to George Edward Moore and Bertrand Russel is a process of analyzing language notions that enable verbalization of the areas resulting from phenomenological empathizing.

However, it should be underlined that while being aware of multidirectional, mutual influence of factors shaping the reality in any of its character, one cannot base his stance on a conviction that analysis is the only right task, which is able to lead to a comprehensible view

12 F. Nietzsche, Wędrowiec ijego cień, Vis-à-vis Etiuda, translated by K. Drzewiecki, Kraków 2015, p. 78.

13 P. Ricoeur, Mitość $i$ sprawiedliwość, TAiWPN UNIVERSITAS, translated by M. Drwięga, Kraków 2010, p. 66. 
of the world. But, despite everything, there is not a possibility to understand the world without language.

\section{Philosophy of dialogue}

St. Augustine underlined that thinking is a constant dialogue with an internal scholar. In this inside human lives Christ, we ask him, he gives answers. The need of dialogue is an essential condition of cognition, both oneself, other person, as well as the subject/phenomenon, which can also be sacrum. Martin Buber wrote about materialized space which is the subject of cognition and dialogue. In his deliberations subjectivity was embedded in a tree. He wrote: „A tree is not an impression, a game of my imagination, a mood value; it lives before me and interacts with as I do with it - only differently"14. If we can have a dialogue with a tree, the more we a partner in such a relation can be architecture.

Each real existence in the world, its understanding and willingness to transform are an encounter in which a mental-emotional discourse is born. Its constant need which simply determines the existence of the subject can be found in the words of Meister Eckhart who wrote that if there wasn't God, there wouldn't be him; if there wasn't him, there wouldn't be the God's Eye with which God sees him, so he is the Eye with which He sees him.

Individuality and subjectivity of every human determine the perception of sacrum by a person. There is not a single egalitarian formula for experiencing and understanding sanctity. Kierkegaard posed a question about the use of so-called objective truth if for him and for his life it did not have a deep, individual meaning.

,Who enters into an absolute relation, that does not care about anything single: things or entities, land or sky but everything consists in the relation" 15 . Here we deal with not with searching the individuality and uniqueness of cognition of a sanctified space but we take a step further which is the essential interaction with it.

In such a time the presence of Good is indispensable. Only thanks to His existence one may touch the mystery. After experiencing many encounters, willing to explain the success of the distance traveled, $\mathrm{He}$ could say that „I emphasize the role of the third part in this trilateral discussion" 16 .

$14 \quad$ M. Buber, Ja i Ty. Wybór pism filozoficznych, transl. J. Doktór, Instytut Wydawniczy Pax, Warszawa 1992, p. 42.

$15 \quad$ Ibidem, p. 87.

16 P. Ricoeur, Czas i opowieść. Czas opowiadany, Wydawnictwo Uniwersytetu Jagiellońskiego eidos, translated by U. Zbrzeźniak, vol. 3, Kraków 2008, p. 181. 
Józef Tischner created a concept of an encounter on a phenomenological plane with a big amount of theistic understanding of the world. In Christian theology we deal with God who created the world as His sacrament. He fill it with animate and inanimate nature, so as humans could interact with it and experience the process of encounters by which contact with God can occur. At such moments the chapters of life in God / in sacrum and life in the world disappear. Hence, being aware of living in architectonic sacrum one reaches the life in God. As a result of the actions done in the world, the Other / God tries to start a talk with a human being, who has an opportunity to start a dialogue with Him. The experience of God's presence has the meaning above all to the one who can anticipate it. The phenomenon of an encounter and a supplementing dialogue always enriches Self with an accurate reflection, arising from the stream of sensations triggered by the Other.

At the moment of perception of an object / architecture a double encoding of its content may be noticed. Both its uniqueness and visuality are seen, as well as content of the acknowledged message of the Creator, which is present in it. A view which functions in the philosophy of dialogue and says that perfect Self does not exists outside the relation with You can be extended by a statement that dialogical relations of Self and Sacrum exist but the involvement of God is essential. It is necessary for full interaction with the sanctified space.

\section{Summary}

The perception of the area of sacred issues, materialized also in the architectonic form, can take place at the syncretic plane of components of the following triumvirate: phenomenology, philosophy of language, philosophy of dialogue

Then a possibility of contact, cognition and dialogue, an accessible sensoric shadow of sacrum, which reveals its Beauty when Truth and Goodness come to existence.

\section{JEDNA Z DRÓG DO ARCHITEKTONICZNEGO SACRUM}

Proces poznania kończy się zazwyczaj próbą nazwania i zrozumienia poszukiwanego/ napotkanego zjawiska. Istota sacrum nie jest obserwowalna, tak jak "Nie mamy przecież bezpośredniego dostępu za pomocą zmysłów do świata kwantowego", a jednak on istnieje. Mając w pamięci słowa L. Wittgensteina, że " granice języka (jedynego języka, jaki rozumiem) oznaczają granice mego świata", należy przejść jedną z dróg prowadzących do naszego przedmiotu poznania. Bezpośrednie zaistnienie w sferze sacrum może być 
Theology of beauty

mentalno-emocjonalną antycypacją istoty przedmiotu dążenia, którego oprawą przestrzenną są niejednokrotnie obiekty architektoniczne. W sensie zmysłowym sacrum materializuje się często w formie: uświęconych kaplic, obrazów, rzeźb, fragmentów budowli, krajobrazu itp. W niniejszym artykule podjęto próbę wskazania jednej z dróg, która może doprowadzić do pełniejszego obcowania i zrozumienia uświęconego, zmaterializowanego zjawiska, któremu często nadaje się imię sacrum. Należy jednak pamiętać, że próba dotarcia do istoty takiego miejsca jest działaniem trudnym, gdyż tak jak „ogląd dzikiego potoku nie dotyczy spływania, szumu i blasków tego indywidualnego potoku, ale ogólnej idei potoku: nieposkromionego parcia naprzód bezforemnej materii", tak i zrozumienie i odczucie sacrum umyka klarownej kodyfikacji.

Słowa kluczowe: język, fenomenologia, filozofia dialogu, filozofia spotkania.

\section{Bibliography:}

1. Borges J. L., Nowa antologia osobista, Wydawnictwo Literackie, translated by A. Sobol-Jurczykowski, Kraków 2006.

2. Buber M., Ja i Ty. Wybór pism filozoficznych, transl. J. Doktór, Instytut Wydawniczy Pax, Warszawa 1992.

3. Eco U., Teoria semiotyki, Wydawnictwo Uniwersytetu Jagiellońskiego EIDOS, translated by M. Czerwiński, Kraków 2009.

4. Heidegger M., Identyczność i różnica, Wydawnictwo Aletheia, translated by J. Mizera, Warszawa 2010.

5. Heidegger M., Podstawowe problemy fenomenologii, Fundacja Aletheia, translated by B. Baran, Warszawa 2009.

6. Heidegger M., W drodze do języka, Wydawnictwo Alethia, translated by J. Mizera, Warszawa 2007.

7. Husserl E., Badania logiczne, Wydawnictwo naukowe PWN, translated by J. Sidorek, vol. 1, Warszawa 2006.

8. Husserl E., Medytacje kartezjańskie, Wydawnictwo IFiS PAN, translated by A. Wajs, Warszawa 2009.

9. Liberkowski R., Przyczynek do fenomenologii życia, Uniwersytet im. A. Mickiewicza w Poznaniu, Wydawnictwo Naukowe Instytutu Filozofii, Poznań 2007.

10. Maciejczak M., Zwrot językowy w filozofii od Fregego do Searle’a, Oficyna Wydawnicza Politechniki Warszawskiej, Warszawa 2010.

11. Nietzsche F., Wędrowiec i jego cień, Vis-à-vis Etiuda, translated by K. Drzewiecki, Kraków 2015.

12. Ricoeur P., Czas i opowieść. Czas opowiadany, Wydawnictwo Uniwersytetu Jagiellońskiego eidos, translated by U. Zbrzeźniak, vol. 3, Kraków 2008.

13. Ricoeur P., Miłość $i$ sprawiedliwość, TAiWPN UNIVERSITAS, translated by M. Drwięga, Kraków 2010.

14. Seel M., Estetyka obecności fenomenalnej, UNIVERSITAS, translated by K. Krzemieniowa, Kraków 2008.

15. Tokarski J. (ed.), Stownik wyrazów obcych PWN, PWN, Warszawa 1980. 